\title{
Expression of prostaglandin D synthetase during development in the mouse testis
}

\author{
P. J. Baker and P. J. O'Shaughnessy* \\ Division of Veterinary Physiology and Pharmacology, Department of Veterinary Preclinical \\ Studies, University of Glasgow Veterinary School, Bearsden Rd, Glasgow G61 1QH, UK
}

\begin{abstract}
Prostaglandin D synthetase is expressed relatively highly in the testis and reproductive tract of a number of species, including the mouse. In adult mouse testis, expression is confined largely to the Leydig cells and in this study changes in the expression and localization of prostaglandin D synthetase mRNA during testis development were examined. Initial studies using RT-PCR and isolated testicular compartments indicated that prostaglandin D synthetase expression in the neonatal testis was predominantly within the seminiferous tubules. In situ hybridization studies confirmed that prostaglandin D synthetase mRNA appears to be expressed only in the tubules of neonatal mouse testes and only in the interstitial tissue of the adult testis. TaqMan real-time PCR was used to quantify prostaglandin D synthetase mRNA content during development using an exogenous mRNA as a control standard. Expression per testis decreased after birth to $<10 \%$ at day 15 before recovering again by days $25-30$.
\end{abstract}

\section{Introduction}

Prostaglandin D synthetase is a $30 \mathrm{kDa}$ peptide that acts to catalyse isomerization of prostaglandin $\mathrm{H}_{2}$ to prostaglandin $\mathrm{D}_{2}$ (Urade et al., 1995). In addition, the primary structure of prostaglandin D synthetase identifies it as a member of the lipocalin superfamily, the members of which are involved in binding and transport of small lipophilic ligands such as retinoids and steroids (Pervaiz and Brew, 1987). Relatively high expression of prostaglandin D synthetase is observed in the testis and reproductive tract of several species including mice (Hoffman et al., 1996; Gerena et al., 2000a), rats (Sorrentino et al., 1998), humans (Blodorn et al., 1996; Tokugawa et al., 1998) and cattle (Rodriguez et al., 2000; Gerena et al., 2000b). Within the testis there is apparent species variation in the site of prostaglandin $D$ synthetase expression, as the protein or mRNA is localized to the Sertoli cells in bulls and rats, and to Leydig cells in mice (Hoffman et al., 1996; Sorrentino et al., 1998; Gerena et al., 2000a,b; Rodriguez et al., 2000). In humans, both the seminiferous tubules and Leydig cells have been reported as

*Correspondence

Email: P.J.O'Shaughnessy@vet.gla.ac.uk
After day 30, expression per testis increased 40-fold during final development to adulthood. Studies using RT-PCR showed that early expression before day 15 was restricted to the tubular compartment, whereas the subsequent increase in expression after day 30 was restricted to the interstitial compartment. Database analysis showed that the 3' end of the prostaglandin D synthetase transcript was subject to alternate splicing. Both splice isoforms were shown by RT-PCR to be present throughout development and without a major change in expression pattern. These results indicate that expression of prostaglandin D synthetase mRNA shifts during development from the tubular compartment of the fetal or neonatal testis to the developing adult Leydig cells, with expression in the Leydig cells increasing markedly after puberty. These changes are similar to those observed for $17 \beta$-hydroxysteroid dehydrogenase type III and may indicate that this developmental process is not uncommon in the testis.

the principal site of prostaglandin D synthetase expression (Bludorn et al., 1996; Tokugawa et al., 1998). The likely function of prostaglandin D synthetase within the testis is not clear. Spermatogenesis is dependent on adequate concentrations of vitamin A and the retinoid bindingtransport capacity of prostaglandin D synthetase may be important in maintaining vitamin $A$ in the tubules. Alternatively, prostaglandin $D_{2}$ is involved in a number of physiological processes including vasodilation (Dumitrascu, 1996) and hormone release (Terao et al., 1995), and may, therefore, play a regulatory role in normal testis function. The developmental profile of prostaglandin D synthetase mRNA expression in the testis is not known and in this study changes in the level and site of prostaglandin D synthetase expression during development in the mouse testis were examined.

\section{Materials and Methods}

\section{Animals and tissues}

Normal mice were bred at the University of Glasgow Veterinary School and maintained as required under United Kingdom Home Office regulations. The mice used were derived from $\mathrm{F} 1$ hybrids of $\mathrm{C} 3 \mathrm{H} / \mathrm{HeH}$ and $101 / \mathrm{H}$ strains. 
Table 1. Primers and probes used for real-time PCR

\begin{tabular}{lll}
\hline Target & Primers and probes $\left(5^{\prime}-3^{\prime}\right)$ \\
\hline Luciferase & $\begin{array}{l}\text { Forward primer } \\
\text { Reverse primer } \\
\text { Probe }\end{array}$ & $\begin{array}{l}\text { TCGAAGTATTCCGCGTACGTG } \\
\text { GCCCTGGTTCCTGGAACAA } \\
\text { TGTTCACCTCGATATGTGCATCTGTAAAAGCA }\end{array}$ \\
$\begin{array}{l}\text { Prostaglandin D } \\
\text { synthetase }\end{array}$ & $\begin{array}{l}\text { Forward primer } \\
\text { Reverse primer } \\
\text { Probe }\end{array}$ & $\begin{array}{l}\text { GGGAATCCCAAGAGACCCAG } \\
\text { GCTCAGCAAATGGCTGC }\end{array}$ \\
\hline
\end{tabular}

The day of birth was designated as day 1 and the mice were killed on days 1, 5, 10, 15, 20, 25, 30 and 40, and when adult animals were aged 90-180 days. Seminiferous tubules and interstitial tissue were separated mechanically as described by O'Shaughnessy et al. (2000) and interstitial tissue webs and tubules were stored frozen in liquid nitrogen until used for RNA extraction.

\section{Reverse transcription and polymerase chain reaction}

RNA was extracted using Trizol (Life Technologies, Paisley) and was reverse-transcribed using random hexamers and Moloney murine leukaemia virus reverse transcriptase (Superscript II; Life Technologies) as described previously (O'Shaughnessy and Murphy, 1993; O'Shaughnesssy and Mannan, 1994). The PCR reactions were performed in Tris- $\mathrm{HCl}$ buffer $\left(75 \mathrm{mmol} \mathrm{I}^{-1}, \mathrm{pH} 9.0\right.$ at $25^{\circ} \mathrm{C}$ ) containing $20 \mathrm{mmol}$ ammonium sulphate $\mathrm{I}^{-1}$, Tween$20(0.01 \% \mathrm{v} / \mathrm{v}), 2 \mathrm{mmol} \mathrm{MgCl}_{2} \mathrm{I}^{-1}, 0.2 \mathrm{mmol} \mathrm{I}^{-1}$ each dNTP, Taq polymerase $(2 \mathrm{U}$ per $100 \mu \mathrm{l}), 200 \mathrm{nmol} \mathrm{I}^{-1}$ each primer and template $(0.1-2.0 \mathrm{ml})$ in a total reaction volume of $30 \mu \mathrm{l}$.

The primers used were based on GenBank sequences (AB006361 and X89222) for mouse prostaglandin D synthetase: forward: 5'-TCAACAAGACAAGTTCCTGG; and reverse: 5'-TGAATTTCTCCTTCAGCTCG. The expected product size was $390 \mathrm{bp}$. The PCR products were separated on a $1 \%(\mathrm{w} / \mathrm{v})$ agarose gel and visualized using ethidium bromide.

The following primers were used to examine expression of alternate transcripts of prostaglandin D synthetase: forward: 5'-GGCCTCACAGAGGACAT; and reverse: 5' CTTGAGAGTGACAGAGCAAG. The expected size of the full-length product was $140 \mathrm{bp}$, whereas the shortened transcript is $107 \mathrm{bp}$. Products of the PCR reactions were separated on a 4\% NuSieve:agarose (3:1) gel (Flowgen, Ashby de la Zouch).

Products from PCR reactions were separated on $1 \%(\mathrm{w} / \mathrm{v})$ agarose gels and visualized with ethidium bromide.

\section{Real-time PCR}

For quantification of the prostaglandin D synthetase mRNA content of testes during development a real-time PCR approach was used, which used the TaqMan PCR method after reverse transcription of the isolated RNA (for review of real-time PCR methodology see Bustin, 2000). In brief, the TaqMan assay uses the 5'-nuclease activity of DNA polymerase to cleave a specific probe that hybridizes to the target amplicon during the annealing and extension phase of the PCR. Each probe contains a fluorescent dye reporter at the $5^{\prime}$ end and a quencher dye at the $3^{\prime}$ end that will normally inhibit the reporter emission. Therefore, cleavage of the probe separates the reporter and quencher dyes, resulting in increased fluorescent emission of the reporter, which is monitored by a suitable detector. The probe also provides an added degree of specificity to the assay. To measure cDNA concentrations the threshold cycle $(\mathrm{C} t)$ at which fluorescence is first detected above baseline is used and a standard curve is drawn between starting cDNA concentrations and $\mathrm{C} t$. In the present study, arbitrary standards were generated by serial dilutions of cDNA prepared from adult testis interstitial tissue. An external standard was used to allow prostaglandin D synthetase mRNA content to be expressed per testis and to control for the efficiency of RNA extraction, RNA degradation and the reverse transcription step. The external standard was luciferase mRNA (Promega UK, Southampton) and 5 ng was added to each testis at the start of the RNA extraction procedure. Prostaglandin D synthetase cDNA content was then expressed relative to luciferase cDNA content in the same sample, to allow direct comparison of expression per testis between different samples.

Primers and probes for use in the TaqMan method were designed using Primer Express (Applied Biosystems, Warrington) (Table 1). RNA was extracted and reversetranscribed as above with the exception that residual genomic DNA was removed by DNAse treatment (DNAfree; Ambion Inc., supplied by AMS Biotechnology), because the TaqMan primers were not specifically designed to produce an amplicon spanning an intron-exon boundary. PCRs were carried out in a $25 \mu \mathrm{l}$ volume using a 96-well plate format. Components for real-time PCR were purchased from Oswel Ltd (Southampton) other than the primers and probes, which came from MWG Biotech (Milton Keynes). Each PCR well contained $1 \times$ reaction buffer (with passive reference), $5 \mathrm{mmol} \mathrm{MgCl}_{2} \mathrm{I}^{-1}$, $200 \mathrm{mmol}^{\mathrm{dNTPs}} \mathrm{I}^{-1}$ (including dUTP), $300 \mathrm{nmol}$ each primer $\mathrm{I}^{-1}, 200 \mathrm{nmol}$ probe $\mathrm{I}^{-1}$ and $0.02 \mathrm{U}$ enzyme $\mu^{-1}$ (Hot GoldStar; Oswel). Reactions were performed and fluorescence detected on a GeneAmp 5700 system (Applied Biosystems). For each sample, a replicate was run omitting 
the reverse transcription step and a template negative control was run for each primer-probe combination.

\section{In situ hybridization}

Testes from fetuses at day 18 of gestation or from adult mice were placed in Bouin's fixative and prepared for in situ hybridization as described by Baker et al. (1999). The 390 bp prostaglandin D synthetase RT-PCR product from adult testis (described above) was cloned into pCRscript (Stratagene Ltd, Cambridge) and sequenced using big dye terminators (Applied Biosystems) to prepare probes for in situ hybridization. Sense and antisense cRNA probes were prepared using T3 and T7 polymerase and were labelled with $\left[{ }^{35} \mathrm{~S}\right] \mathrm{dUTP}$. Tissue sections $(7 \mathrm{~mm})$ were hybridized overnight at $60^{\circ} \mathrm{C}$ with probe $(100000$ c.p.m. ml-1) in hybridization buffer $(50 \%(\mathrm{v} / \mathrm{v})$ deionized formamide, $10 \%$ $(\mathrm{w} / \mathrm{v})$ dextran sulphate, $50 \mathrm{mmol}$ dithiothreitol $\mathrm{I}^{-1}, 500 \mathrm{mg}$ calf thymus DNA ml-1, $1 \times$ Denhardt's solution, $20 \mathrm{mmol}$ Tris- $\mathrm{HCl} \mathrm{I-1}, \mathrm{pH} 8.0,5 \mathrm{mmol}$ EDTA $\mathrm{I}^{-1}$ and $10 \mathrm{mmol}$ sodium phosphate $\mathrm{I}^{-1}, \mathrm{pH}$ 6.8). After hybridization, the slides were washed, dehydrated and allowed to air dry. Autoradiography was carried out using Ilford K5 emulsion (Ilford) and the slides were stained with Meyer's haematoxylin and eosin (Merck Ltd, Lutterworth).

\section{Results}

Localization of prostaglandin D synthetase mRNA expression in the testis

$R T-P C R$. In initial studies to examine localization of prostaglandin D synthetase in mouse testis the interstitial and tubular compartments from adult and neonatal testes were isolated and cDNA was prepared. Amplification of this CDNA using primers designed to amplify prostaglandin $\mathrm{D}$ synthetase indicated that prostaglandin D synthetase was expressed predominantly in the interstitial compartment of the adult testis and in the tubular compartment of the neonatal testis (Fig. 1).

In situ hybridization. A cRNA probe was hybridized to sections from adult and late fetal testes to confirm localization of prostaglandin D synthetase expression. In the adult testes, grains were clearly localized to the interstitial tissue with little or no apparent hybridization within the tubules (Fig. 2d,f). In the fetus, hybridization was limited to the tubular areas (Fig. 2a,b) and Leydig cells appeared to be largely devoid of grains (arrowhead, Fig. $2 b)$.

\section{Developmental changes in prostaglandin D synthetase expression}

Real-time PCR. Curves were prepared using serial dilutions of an arbitrary sample of cDNA and the threshold cycle $(C t)$ at which amplification was first detectable above background was plotted against the relative cDNA

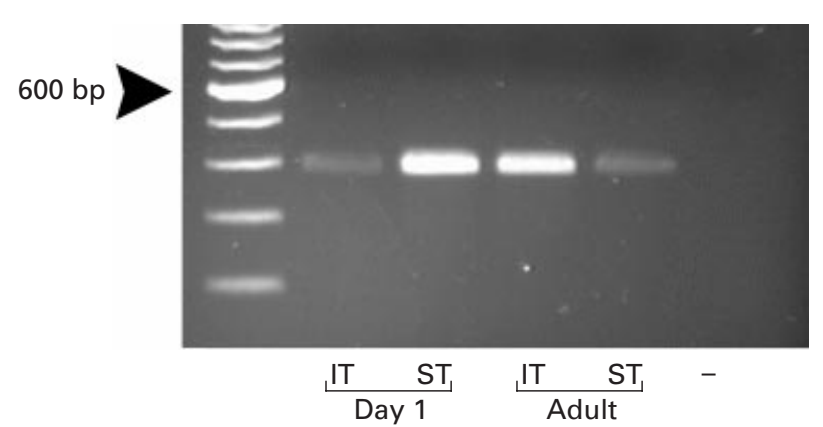

Fig. 1. Expression of prostaglandin $D$ synthetase in different compartments of neonatal (day 1) and adult mouse testis. cDNA was prepared from interstitial tissue (IT) or seminiferous tubules (ST) of neonatal or adult testes and amplified by PCR over 30 cycles using primers specific to prostaglandin D synthetase. A 100 bp ladder was included in the first lane and a tissue blank (-) in the last lane.

concentration (Fig. 3a) to characterize amplification of prostaglandin D synthetase and luciferase cDNA using TaqMan probes. The slope of the curve is inversely proportional to the efficiency of the reaction with a slope of -1.4427 equivalent to $100 \%$ efficiency. It is necessary to show that the curves are not significantly non-parallel (that the amplification efficiencies are not significantly different) to be able to compare prostaglandin D synthetase cDNA content directly with that of luciferase and this was tested using two-factor ANOVA. The efficiencies of the PCR reactions were similar for probes used in this study $(96.6 \%$ versus $95.6 \%$, Fig 3a) and the interaction factor from ANOVA was not significant. Therefore, the ratio of prostaglandin D synthetase cDNA:luciferase cDNA was calculated from the difference between the $C t$ values $(\Delta C t)$.

Developmental changes in mRNA content per testis. Accumulated data from a study of changes in prostaglandin D synthetase mRNA expression during postnatal testis development are shown (Fig. 3b). These results show that expression decreases after birth by $>90 \%$ to a nadir at day 15. Thereafter, there is an increase in expression until days 25-30, at which time expression per testis is similar to that on the day of birth. After day 30, expression of prostaglandin D synthetase mRNA increases more than tenfold up to day 40 with a further four- to fivefold increase up to adulthood (Fig. 3b).

Changes in localization of expression. RT-PCR was performed using RNA extracted from tubules and interstitium of mice aged 1, 5, 10,20,30, 40 and 90 days to determine the age at which expression of prostaglandin $D$ synthetase mRNA changes from the tubular compartment of the testis to the interstitial compartment (Fig. 4). On days 1 and 5, expression was confined largely to the tubular compartment with only low expression apparent in the interstitial tissue. At days 10 and 20 there was no detectable prostaglandin D synthetase expression (up to 30 cycles of 

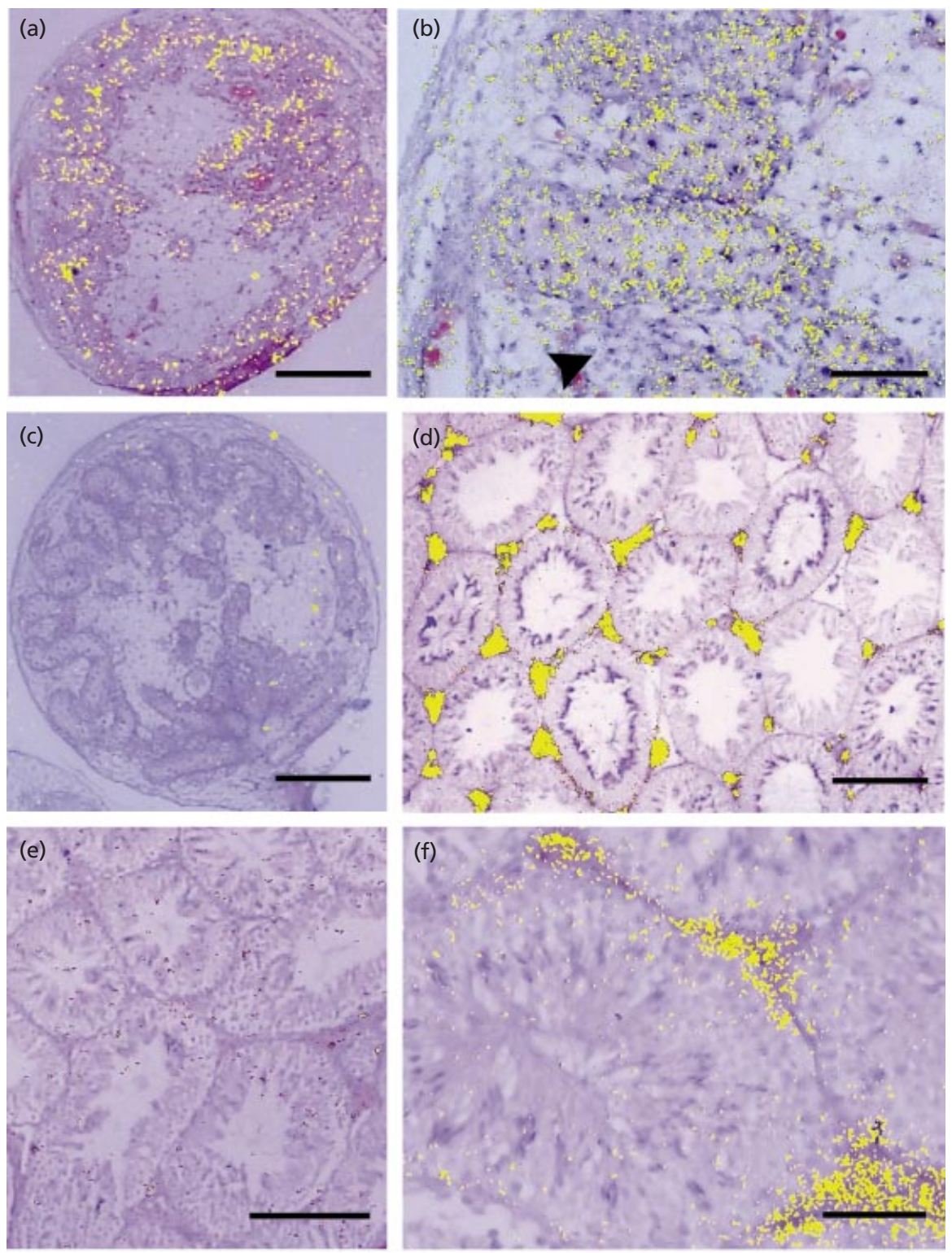

Fig. 2. In situ hybridization showing prostaglandin D synthetase mRNA expression in fetal (day 18 of gestation) and adult mouse testes. (a) and (d) are low-power photomicrographs showing anti-sense probe hybridization to fetal and adult testes, respectively. (b) and (f) are higher power photomicrographs showing anti-sense probe hybridization to fetal and adult testes, respectively. The black arrowhead in (b) indicates a group of fetal Leydig cells that show no hybridization. (c) and (e) show hybridization by a sense control probe in fetal and adult testis. Scale bar represents $200 \mu \mathrm{m}$ (a,c,d,e) or $50 \mu \mathrm{m}(\mathrm{b}, \mathrm{f})$.

PCR) in either compartment. By day 30, expression was detectable again but was confined mainly to the interstitial compartment and this localization was maintained in day 40 and adult mice.

Alternate splicing. There are two sequences of prostaglandin D synthetase in GenBank and comparison with the mouse EST database identified two different 3' endings that differed by 33 bases. The longer ending is exemplified by AB006361, whereas the shorter ending lacks bases 641-673 of this sequence (Fig. 5). Primers were designed that spanned the alternate region and RT-PCR was performed using RNA from day 1 , day 30 and adult testes to show which isoform is predominant in vivo and to determine whether there is a change in expression during development. The results indicate that both isoforms are expressed at all three ages and that expression of the two isoforms appears similar, at least after day 1 (Fig. 6). 
(a)

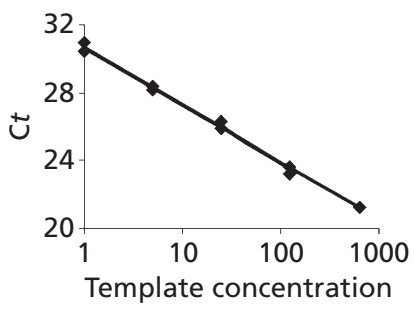

(b)

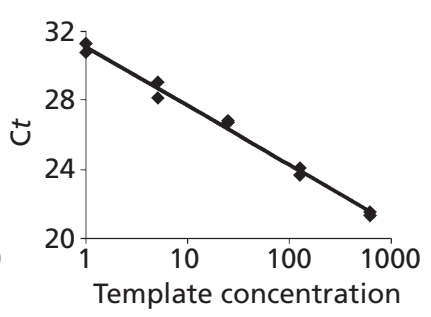

(c)

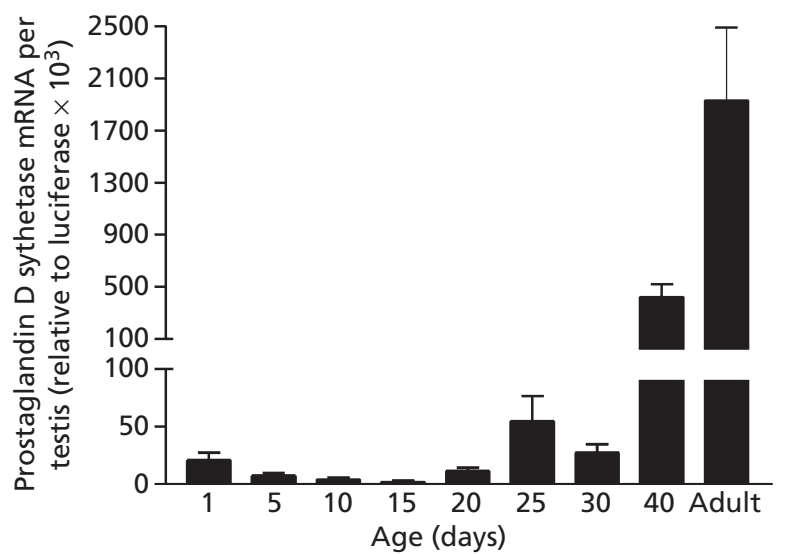

Fig. 3. Real-time PCR amplification of (a) prostaglandin D synthetase and (b) luciferase cDNA. Standard curves prepared by serial dilutions of adult testis cDNA. The log of the relative template concentration was plotted against the threshold cycle $(\mathrm{C} t)$ and regression analysis was used to generate the best-fit line. The formula given for each curve (prostaglandin $\mathrm{D}$ synthestase: $y=-1.4797 \ln (x)+30.702 ;$ and luciferase: $y=-1.4903 \ln (x)+$ $31.127)$ describes that line and the slope of the line can be used to determine the efficiency of the PCR reaction. In this case amplification of prostaglandin D synthetase was $96.6 \%$ efficient and luciferase was $95.6 \%$ efficient. (c) Cumulative data showing prostaglandin D synthetase mRNA content, relative to added luciferase control, during development. Results are mean \pm SEM ( $n=3-6$ animals in each group).

\section{Discussion}

The results of the present study indicate that testicular expression of prostaglandin D synthetase is confined largely to the tubules during fetal and postnatal development and that this expression then shifts to the Leydig cells at about the time of puberty. The shift to the Leydig cells is followed by a marked increase in expression, which starts between day 30 and day 40 and continues into adulthood. These changes in expression pattern are very similar to the changes in 17ß-hydroxysteroid dehydrogenase type III expression observed during development of the mouse testis (O'Shaughnessy et al., 2000), thereby indicating that shifts in specific mRNA expression from the tubules to the developing adult Leydig cells may not be uncommon.

In the present study, real-time PCR was used to quantify

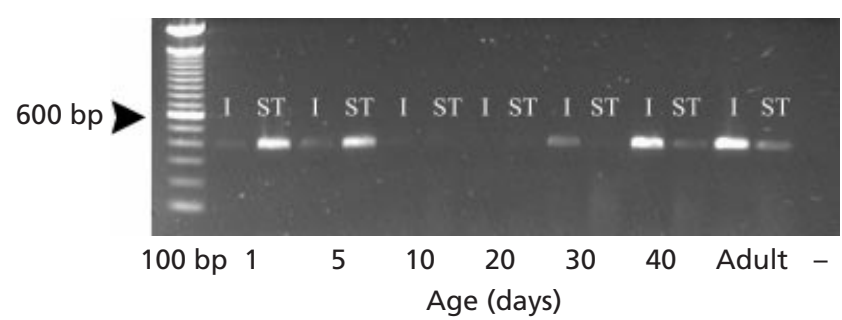

Fig. 4. Expression of prostaglandin $D$ synthetase in interstitial tissue (I) and seminiferous tubules (ST) from mice aged day 1 to adulthood. Interstitial tissue and seminiferous tubules were isolated from animals of different ages and cDNA was prepared. This cDNA was amplified for 30 cycles with primers specific to prostaglandin D synthetase. A 100 bp ladder was included in the first lane and a tissue blank (-) was included in the last lane.

prostaglandin D synthetase mRNA content during development. A housekeeping gene such as $\beta$-actin or GAPDH is commonly used in this kind of study as an internal standard to correct for differences in total mRNA content between samples. In developmental studies of the testis, problems arise because not only is there an overall change in the total mRNA content as the tissue grows but there is also a marked change in the proportion of different cell types in the testis as spermatogenesis progresses. An internal standard can be useful under these conditions only if it is expressed equally in all cells at all stages of development, which is probably not the case for the commonly used standards and, in particular, $\beta$-actin (Velculescu et al., 1999; Medhurst et al., 2000). An external mRNA was used as a control in the present study to avoid this problem. Provided that an equal amount of this mRNA is added to all tissues and provided that it behaves in the same way as endogenous RNA, then expressing endogenous mRNA relative to the external standard allows direct comparison of expression between tissues of different mass and composition to be made.

The results of the quantitative study of prostaglandin D synthetase expression during development indicate that there is a decrease in expression after birth followed by a marked increase in expression around puberty. Localization studies using RT-PCR and different testicular compartments indicate that the decrease after birth is due to loss of expression in the tubules, whereas the increase in expression after day 20 is due to increasing expression within the Leydig cells. The adult population of Leydig cells arises at about days 7-10 in mice (Baker et al., 1999; Nef et al., 2000) and the timing of prostaglandin D synthetase expression indicates that it arises relatively late in adult Leydig cell development. The rat testis shows a similar increase in expression after puberty, although there are no clear changes in expression between birth and day 10 in rats (Samy et al., 2000). This may be due to the less sensitive methods used by Samy et al. (2000), although it is not clear which cell type is the major source of prostaglandin D synthetase in rats. Sertoli cells have been shown to express prostaglandin D synthetase in rats (Sorrentino et al., 1998) 


\section{........GAT AAG TGC ATT CAA GAG TAA acgcaggtgagagaagtcagtcagagggctggtcacatggtga \\ $\begin{array}{llllllll}\ldots & \mathrm{D} & \mathrm{K} & \mathrm{C} & \mathrm{I} & \mathrm{Q} & \mathrm{E} & \text { stop }\end{array}$ \\ cctggectcaggactccettgetctgtcactctcaagatcccagecetggetccccaaagtacctctacaccetccagetttgcettgac}

aaagaaataaaagtccaaagcaagtc

Fig. 5. Sequence of the prostaglandin D synthetase 3' region showing the 3' end of the open-reading frame and the $3^{\prime}$ untranslated region. The alternately spliced sequence within the $3^{\prime}$ untranslated region is outlined in a box. The polyadenylation site is underlined.

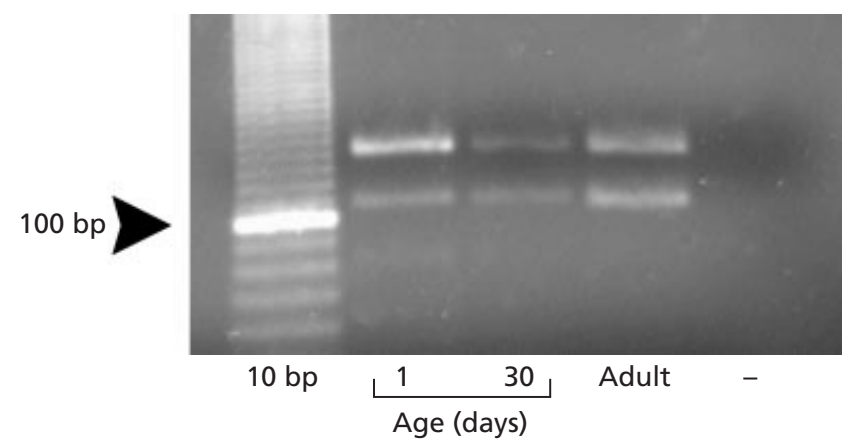

Fig. 6. Expression of alternate transcripts of prostaglandin D synthetase by testes from mice at different ages. cDNA was prepared from whole testes of animals aged 1 day, 30 days and adult and amplified using primers designed specifically to span both alternate transcripts. Lane 1 contained a $10 \mathrm{bp}$ ladder and the last lane was a control without tissue (-). The expected sizes of the transcripts were $140 \mathrm{bp}$ and $107 \mathrm{bp}$.

but there have been no localization studies in the whole testis.

As with $17 \beta$-hydroxysteroid dehydrogenase type III, it is not clear why prostaglandin D synthetase expression in the tubules decreases after birth. The Sertoli cells are still undergoing active proliferation at this time (Vergouwan et al., 1993) and occluding junctions are starting to develop between cells (Nagano and Suzuki, 1976; Kluin et al., 1984). Androgen receptor expression is first apparent in the Sertoli cells at about this time (You and Sar, 1998), indicating that the cells are becoming androgen-sensitive. It is possible that this may act as a trigger to alter the pattern of gene expression within the Sertoli cells. It has been suggested on the basis of immunocytochemical localization that Sertoli cells at stages VI-VIII continue to express prostaglandin D synthetase (Gerena et al., 2000) in adult mice. However, two studies using in situ hybridization (present study and Hoffman et al., 1996) have failed to detect significant expression in the Sertoli cells, suggesting either that mRNA content is very low or that the protein has a different site of origin.

The shift in prostaglandin D synthetase expression from Sertoli cells to the Leydig cells may implicate this protein in androgen biosynthesis, particularly as the pattern of expression is similar to that of $17 \beta$-hydroxysteroid dehydrogenase type III, which is involved intimately in androgen synthesis by the Leydig cells. Prostaglandin D synthetase binds to retinoic acid and retinal and it may act as a retinoid-binding protein (Tanaka et al., 1997). Retinoids have been implicated in the growth, development and function of many different cell types, including Leydig cells (Chaudhary et al., 1991; Lefevre et al., 1994; Lee et al., 1999), and it is possible that prostaglandin D synthetase may regulate retinoid concentrations in the environment of the Leydig cells. Alternatively, retinoids are required for maintenance of spermatogenesis (Mitranond et al., 1979; Van Pelt and de Rooij, 1990) and Leydig cell-derived prostaglandin D synthetase may act as a carrier in the movement of retinoids to the tubule lumen. It is interesting that the source of prostaglandin D synthetase varies among species, with Leydig cells in mice and humans the major or only source, whereas in bulls Sertoli cells are the only source (this study; Hoffman et al., 1996; Gerena et al., 2000b; Rodriguez et al., 2000). This finding implies either that the role of prostaglandin D synthetase varies among species or that within the testis the source is not relevant, with prostaglandin D synthetase able to function at a distance from the cell of origin as required. It should be noted that prostaglandin D synthetase-null mice are fertile, indicating that the role of prostaglandin $\mathrm{D}$ synthetase in the testis can be assumed by other factors such as the cellular retinoic acid-binding proteins (Eguchi et al., 1999).

The significance of alternate splicing in the $3^{\prime}$ untranslated region of the prostaglandin $D$ synthetase transcripts is not known. Regions within the $3^{\prime}$ untranslated region can regulate the stability of mRNA and it is possible that these alternate transcripts have different stabilities in the cell. It is noticeable that the sequence around the splice sites corresponds poorly to the consensus sequences for eukaryote splicing (Smith et al., 1989). In addition, the five bases immediately upstream of the alternately spliced sequence (GGTGA) are identical to the five bases at the $3^{\prime}$ end of the spliced sequence. It is possible that if the spliced region is a short exon, or is at the downstream end of an exon, then either sequence may be used as the $5^{\prime}$ splice donor site leading to constitutive splicing. Despite the expression of prostaglandin D synthetase in two different cell types during development, the results of the present study showed that there were no marked changes in the abundance of the splice forms, which is consistent with this hypothesis of constitutive splicing.

The results of the present study show that expression of prostaglandin D synthetase mRNA shifts during development from the seminiferous tubules of the fetal or neonatal 
testis to the adult Leydig cell population in the post-pubertal testis. There are striking similarities with the developmental pattern of $17 \beta$-hydroxysteroid dehydrogenase type III, indicating that the adult Leydig cell population assumes a number of the functions that the Sertoli cells express during fetal development.

This study was supported by an award from the BBSRC. The authors would like to thank $\mathrm{G}$. Jackson for technical assistance.

\section{References}

Baker PJ, Sha JA, McBride MW, Peng L, Payne AH and O'Shaughnessy PJ (1999) Expression of 3ß-hydroxysteroid dehydrogenase type I and VI isoforms in the mouse testis during development European Journal of Biochemistry 260 911-916

Blodorn B, Mader M, Urade Y, Hayaishi O, Felgenhauer $\mathrm{K}$ and Bruck $\mathrm{W}$ (1996) Choroid plexus: the major site of mRNA expression for the betatrace protein (prostaglandin D synthase) in human brain Neuroscience Letters 209 117-120

Bustin SA (2000) Absolute quantification of mRNA using real-time reverse transcription polymerase chain reaction assays Journal of Molecular Endocrinology 25 169-193

Chaudhary LR, Hutson JC and Stocco DM (1989) Effect of retinol and retinoic acid on testosterone production by rat Leydig cells in primary culture Biochemical and Biophysical Research Communications 158 400-406

Dumitrascu D (1996) Mast cells as potent inflammatory cells Rome Journal of Internal Medicine 34 159-172

Eguchi N, Minami T, Shirafuji N et al. (1999) Lack of tactile pain (allodynia) in lipocalin-type prostaglandin D synthase-deficient mice Proceedings National Academy of Sciences USA 96 726-730

Gerena RL, Eguchi N, Urade Y and Killian GJ (2000a) Stage and regionspecific localization of lipocalin-type prostaglandin D synthase in the adult murine testis and epididymis Journal of Andrology 21 848-854

Gerena RL, Irikura D, Eguchi N, Urade Y and Killian GJ (2000b) Immunocytochemical localization of lipocalin-type prostaglandin D synthase in bull testis and epididymis and on ejaculated sperm Biology of Reproduction 62 547-556

Hoffmann A, Bachner D, Betat N, Lauber J and Gross G (1996) Developmental expression of murine $\beta$-trace in embryos and adult animals suggests a function in maturation and maintenance of blood-tissue barriers Developmental Dynamics 207 332-343

Kluin PhM, Kramer MF and de Rooij DG (1984) Proliferation of spermatogonia and Sertoli cells in maturing mice Anatomy and Embryology 169 73-78

Lee HK, Yoo MS, Choi HS, Kwon HB and Soh J (1999) Retinoic acids upregulate steroidogenic acute regulatory protein gene Molecular and Cellular Endocrinology 148 1-10

Lefevre A, Rogier E, Astraudo C, Duquenne C and Finaz C (1994) Regulation by retinoids of luteinizing hormone/chorionic gonadotropin receptor, cholesterol side-chain cleavage cytochrome P-450, 3 $\beta$ hydroxysteroid dehydrogenase/delta (5-4)-isomerase and $17 \alpha$ hydroxylase/C17-20 lyase cytochrome P-450 messenger ribonucleic acid levels in the K9 mouse Leydig cell line Molecular and Cellular Endocrinology 106 31-39

Medhurst AD, Harrison DC, Read SJ, Campbell CA, Robbins MJ and Pangalos MN (2000) The use of TaqMan RT-PCR assays for semiquantitative analysis of gene expression in CNS tissues and disease models Journal of Neuroscience Methods 98 9-20

Mitranond V, Sobhon P, Tosukhowong P and Chindaduangrat W (1979) Cytological changes in the testes of vitamin-A-deficient rats. I.
Quantitation of germinal cells in the seminiferous tubules Acta Anatomica 103 159-168

Nagano T and Suzuki F (1976) The postnatal development of the junctional complexes of the mouse Sertoli cells as revealed by freeze fracture Anatomical Record 185 403-418

Nef S, Shipman T and Parada LF (2000) A molecular basis for estrogeninduced cryptorchidism Developmental Biology 224 354-361

O'Shaughnessy PJ and Mannan MA (1994) Development of cytochrome P450 side chain cleavage mRNA levels in neonatal ovaries of normal and hypogonadal (hpg) mice Molecular and Cellular Endocrinology 104 133-138

O'Shaughnessy PJ and Murphy L (1993) Cytochrome P-450 17 $\alpha$ hydroxylase protein and mRNA in the testis of the testicular feminized (Tfm) mouse Journal of Molecular Endocrinology 11 77-82

O'Shaughnessy PJ, Baker PJ, Heikkila M, Vainio S and McMahon AP (2000) Localization of 17ß-hydroxysteroid dehydrogenase/17-ketosteroid reductase isoform expression in the developing mouse testis androstenedione is the major androgen secreted by fetal/neonatal Leydig cells Endocrinology 141 2631-2637

Pervaiz S and Brew K (1987) Homology and structure-function correlations between a1-acid glycoprotein and serum retinol-binding protein and its relatives FASEB Journal 1 209-214

Rodriguez CM, Day JR and Killian GJ (2000) Expression of the lipocalintype prostaglandin D synthase gene in the reproductive tracts of Holstein bulls Journal of Reproduction and Fertility 120 303-309

Samy ET, Li JC, Grima J, Lee WM, Silvestrini B and Cheng CY (2000) Sertoli cell prostaglandin D2 synthetase is a multifunctional molecule: its expression and regulation Endocrinology 141 710-721

Smith CWJ, Patton JG and Nadal-Ginard B (1989) Alternative splicing in the control of gene expression Annual Reviews of Genetics 23 527-577

Sorrentino C, Silvestrini B, Braghiroli L et al. (1998) Rat prostaglandin D2 synthetase: its tissue distribution, changes during maturation, and regulation in the testis and epididymis Biology of Reproduction $\mathbf{5 9}$ 843-853

Tanaka T, Urade Y, Kimura H, Eguchi N, Nishikawa A and Hayaishi $O$ (1997) Lipocalin-type prostaglandin D synthase ( $\beta$-trace) is a newly recognized type of retinoid transporter Journal of Biological Chemistry $27215789-15795$

Terao A, Kitamura H, Asano A, Kobayashi M and Saito M (1995) Roles of prostaglandins D2 and E2 in interleukin-1-induced activation of norepinephrine turnover in the brain and peripheral organs of rats Journal of Neurochemistry 65 2742-2747

Tokugawa Y, Kunishige I, Kubota Y et al. (1998) Lipocalin-type prostaglandin $\mathrm{D}$ synthase in human male reproductive organs and seminal plasma Biology of Reproduction 58 600-607

Urade Y, Watanabe K and Hayaishi O (1995) Prostaglandins D, E, F synthases Journal of Lipid Mediators and Cell Signaling 12 257-273

van Pelt AM and de Rooij DG (1990) Synchronization of the seminiferous epithelium after vitamin A replacement in vitamin A-deficient mice Biology of Reproduction 43 363-367

Velculescu VE, Madden SL, Zhang L et al. (1999) Analysis of human transcriptomes Nature Genetics 23 387-388

Vergouwen RPFA, Huiskamp R, Bas RJ, Roepers-Gajadien HL, Davids JAG and de Rooij DG (1993) Postnatal development of testicular populations in mice Journal of Reproduction and Fertility 99 479-485

You L and Sar M (1998) Androgen receptor expression in the testes and epididymides of prenatal and postnatal Sprague-Dawley rats Endocrine $9253-261$

Received 16 March 2001.

First decision 14 May 2001.

Accepted 20 June 2001. 